\title{
TADUMBURAKE ANU KEANGGA: MENYOAL TEOLOGI RAHIM PEREMPUAN DI POSO
}

\section{Gede Supradnyana}

\author{
Dosen STT Gereja Kristen Sulawesi Tengah \\ Email: gede.sttgkst@gmail.com
}

\begin{abstract}
The womb and woman are two inseparable things. In a woman's body there is a uterus. If so, respecting and honoring the womb is synonymous with respecting and respecting women. But the course of human history shows that the womb no longer belongs to women, and everything that accompanies it is fully controlled by male domination (patriarchy). This paper will discuss the theological perspective on the uterus. In this paper, the author does not pretend to be a feminist theologian. However, the perspective of feminist theology is used in the discussion and analysis throughout this articles.
\end{abstract}

Keywords: Womb, Feminist, Poso

\begin{abstract}
Abstrak
Rahim dan perempuan adalah dua hal yang tak dapat dipisahkan. Dalam tubuh perempuanlah terdapat rahim. Bila demikian, menghargai dan menghormati rahim sinonim dengan menghargai dan menghormati perempuan. Akan tetapi perjalanan sejarah manusia menunjukkan bahwa rahim tak lagi menjadi milik perempuan, dan segala hal yang menyertainya sepenuhnya dikontrol oleh dominasi laki-laki (patriarki). Tulisan ini hendak membahas tentang perspektif teologis mengenai rahim. Dalam tulisan ini, penulis tidak berpretensi menjadi seorang teolog feminis. Namun demikian, perspektif teologi feminis digunakan dalam pembahasan dan analisis di sepanjang tulisan ini.
\end{abstract}

Kata Kunci: Rahim, Feminis, Poso 


\section{PENDAHULUAN}

Rahim adalah sebuah kata Arab, yang serumpun dengan bahasa-bahasa Semit, termasuk Ibrani. Merujuk ke Theological Word of Old Testament Lexicon, Perjanjian Lama Ibrani menggunakan akar kata (rkhm). Dari situ muncul kata ( r $^{1}$ am) "sangat mengasihi, menaruh belas kasihan, berbelas kasih"; juga kata

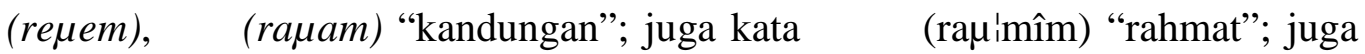

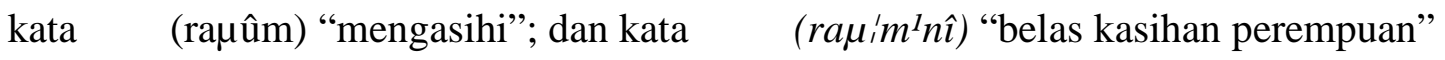
(di Rat. 4:10 LAI menggunakan terjemahan “wanita yang lemah lembut”).

Sedangkan kata rahim dalam bahasa Yunani ialah кoı $\lambda i ́ \alpha$ (koilia). Baik dalam Septuaginta (Perjanjian Lama berbahasa Yunani) dan Perjanjian Baru dengan merujuk kepada Thayer's Greek Lexicon, kata tersebut memiliki beragam arti. Misalnya rahim/kandungan, dan juga jiwa, hati. Koilia, dalam terjemahan yang terakhir, jiwa/hati, dimaknai dalam pengertian sebagai sarana untuk berpikir, merasa, dan mengambil keputusan.

Berdasarkan pengertian akar katanya, maka jelaslah bahwa konsep rahim mendapat posisi sentral dalam Kitab Suci. Apabila memperhatikan makna pada masing-masing, baik dalam bahasa Ibrani maupun bahasa Yunani, ditemukan bahwa konsep rahim (perempuan) selain dimaknai sebagai kandungan juga menjadi penggambaran bagi sifat Allah, yakni Allah yang berbelas kasih dan penuh rahmat. Konsep yang sama dapat juga ditemukan di Al-Quran, dimana Allah disebut ArRahman dan Ar-Rahim (Maha Pemurah dan Maha Penyayang) [Al-Fatiha: 1]. ${ }^{1}$ Mengapa Allah digambarkan sebagai Dia yang merahmati dan merahimi? Ini adalah suatu penggambaran yang sangat feminin. Dengan kata lain, mengapa rahim dipakai sebagai penggambaran untuk Allah?

Tampaknya tidak ada penggambaran untuk menjelaskan tindakan Allah yang secara aktif berbelas kasih kepada umat-Nya. Rahim adalah metafora yang tepat untuk menjelaskan sifat Allah itu. Alkitab pun dengan gamblang menyatakan tindakan Allah kepada umat-Nya laksana seorang ibu yang merawat janin dalam kandungannya, bahkan lebih dari itu. "Dapatkah seorang perempuan melupakan bayinya, sehingga ia tidak menyayangi anak dari kandungannya? Sekalipun dia melupakannya, Aku tidak akan melupakan engkau." (Yes. 49:15).

Sekurang-kurangnya terdapat beberapa penjelasan terhadap penggambaran ini.

Pertama, Allah Sang Maha Rahim adalah Dia yang memilih umat-Nya tanpa syarat; 
seperti rahim perempuan yang tak pernah memilih janin yang dibesarkannya, apapun keadaannya. Kedua, rahmat dan kasih Allah kepada umat-Nya mengatasi murkaNya; seperti rahim perempuan yang memandang geliat janin yang menyakitkan/menjengkelkan dengan penuh kasih sayang. Ketiga, Allah tak pernah lelah dan terus sabar untuk mengasihi umat-Nya; seperti rahim perempuan yang tabah untuk memberi yang terbaik bagi janin. Keempat, Allah tak pernah memutus hubungan/perjanjian kasih dengan umat-Nya; seperi rahim yang tak pernah menuntut kompensasi atas "jasa”-nya.

\section{- Pengalaman Ketubuhan Perempuan Dalam Kontrol Laki-Laki (Patriarki)}

Metafora alkitabiah tersebut di atas tampak sangat ideal, mengingat banyaknya persoalan yang dihadapi oleh perempuan di sekitar rahimnya sendiri. Menurut Lupton, sebagaimana dikutip Abdullah, rahim perempuan memiliki implikasi yang luas dalam penataan sosial masyarakat. ${ }^{2}$ Oleh karena rahimlah maka perempuan mengalami menstruasi, kehamilan, melahirkan, dan juga menopause, dan inilah yang dipandang sebagai kodrat perempuan, yang membedakannya dengan laki-laki. Segala proses yang terjadi di dalam rahim membuat perempuan mengalami "sakit" bawaan yang berpengaruh pada seluruh tubuhnya. Sesehat apapun fisik seorang perempuan, kondisi tersebut membuatnya pasti terkena "penyakit perempuan". Sementara itu, bagi laki-laki kita tidak mengenal "penyakit laki-laki" yang serupa dengan penyakit yang diderita oleh perempuan.

Menariknya, pengalaman ketubuhan (rahim) perempuan tersebut berperan menentukan penataan sosial yang diatur oleh laki-laki. Sudah sejak lama dalam perjalanan sejarahnya, bahkan hingga kini, tubuh perempuan yang di dalamnya terdapat Rahim itu dilihat hanya sebagai organ reproduksi semata. Karena itu, baik laki-laki maupun perempuan menantikan datangnya haid pertama yang menjadi tanda bahwa rahim perempuan siap untuk dibuahi. Pandangan ini memahami bahwa perempuan baru akan disebut perempuan "sejati" atau "sempurna" apabila telah menjalankan fungsi reproduksi. Hal ini kemudian berkembang menjadi "kodratisasi" pengalaman tubuh perempuan, sdan celakanya, sebagai kodrat, pengalaman itu tidak dipandang istimewa.

Menstruasi, misalnya, merupakan sebuah proses biologis normal yang menunjukkan bahwa rahim seorang perempuan sedang sehat karena hormon seksualnya berfungsi 
baik. Tetapi, oleh masyarakat, bahkan oleh perempuan sendiri, menstruasi dipandang sebagai "penyakit" bulanan yang dapat mengganggu aktifitas, termasuk (katanya) psikologis perempuan (pre-menstrual syndrome). Akibatnya, menstruasi dipandang kotor dan jijik sehingga menjadi sesuatu yang merugikan dan ditabukan; rugi sebab tidak bisa berhubungan seks dan tabu (pada agama tertentu) sebab tidak boleh beribadah.

Selanjutnya, eksploitasi juga dapat terjadi pada tubuh (rahim) perempuan, sekurang-kurangnya untuk dua hal. Pertama, pada keluarga dan budaya yang menginginkan jenis kelamin tertentu, umumnya anak laki-laki, karena dapat dianggap sebagai penerus nama keluarga (patrilineal). Hal ini juga berlaku mereka yang menginginkan anak dengan jumlah tertentu. Kedua, di masyarakat patriarki, rahim perempuan cenderung disalahkan bila tidak mampu menjalani "kodrat"nya untuk mengandung dan melahirkan keturunan. Padahal berkaitan dengan kehamilan bukan hanya merupakan persoalan perempuan, tapi juga masalah laki-laki. Tuduhan yang paling sering adalah bahwa "kemandulan" terjadi pada rahim perempuan. Sementara faktanya, laki-laki juga dapat mengalami kemandulan yang menyebabkan kehamilan tak kunjung terjadi.

Hal tersebut di atas juga menunjukkan bahwa rahim, sebagaimana disebutkan Noviani, menunjukkan multiplisitas (jamak) wajahnya. ${ }^{3}$ Melalui rahim yang mengandung, perempuan dapat dipuja-puji karena memenuhi tuntutan keluarga dan masyarakat. Sebaliknya, melalui rahim yang mengandung pula, perempuan dapat dicaci maki karena tak sesuai dengan norma-norma yang diterima masyarakat. Bukan hanya itu saja, bahkan pada saat rahim tak mampu menghidupi janinnya, perempuan dipandang rendah karena dianggap kehilangan kesempurnaan. Oleh karena itu, dalam pandangan masyarakat rahim dapat menjadi produktif tapi juga dapat menjadi destruktif bagi pemiliknya.

Menopause pun seringkali dipahami sebagai penyakit. Sejatinya, proses berakhirnya siklus menstruasi secara alami ini justru ditakuti oleh perempuan karena dapat membuat terjadinya berbagai perubahan dalam hidupnya. Dilansir dari situs www.alodokter.com menopause dapat menyebabkan perubahan penampilan fisik, kondisi psikologis, hasrat seksual, hingga kesuburan seorang perempuan. Hal yang paling dikuatirkan, sebagaimana dikatakan South-Paul dkk., bahwa menopause 
menyebabkan masalah pada daur seksual perempuan dan masalah seputar pelumasan dan orgasmenya. ${ }^{4}$

Persoalan lainnya ialah apabila rahim "tak digunakan", atau dengan kata lain, perempuan yang tidak menikah. (Rahim) perempuan itu rentan untuk dilecehkan, ia menjadi gunjingan dan ditertawakan untuk dua hal: sebagai yang tidak laku, sekaligus sebagai yang berpotensi untuk "merebut" laki-laki. Maka perempuan yang satu akan menganggap (rahim) perempuan yang lain sebagai ancaman.

Terakhir, bila seorang perempuan hamil dan meninggal, ia direndahkan sebagai yang berpotensi untuk menjadi puntianak (singkatan dari "perempuan mati beranak" [dilansir dari Wikipedia: Kuntilanak]) yang meneror perempuan hamil atau bayi-bayi yang sedang tidur. Rahim malang tersebut dipandang sebagai penyebab seorang perempuan seketika berubah menjadi makhluk horor. Ritual-ritual khusus pun dilakukan supaya teror itu tidak terjadi, misalnya dengan menaruh telur pada genggamannya.

Mengapa rahim perempuan dipandang sedemikian dan perempuan justru takut pada kondisi normal "kerahiman"-nya? Inilah konstruksi masyarakat yang mengagungkan laki-laki dan menempatkan perempuan sebagai pelayan kebutuhan dan kepuasan kaum laki-laki (patriarki). Perempuan takut jika tidak dapat melayani suaminya ketika menstruasi; perempuan takut jika suaminya meninggalkannya bila ia tak dapat memberikan keturunan atau jika tidak dapat memberi keturunan sesuai dengan jenis kelamin yang diingini. Selain itu, perempuan pun takut jika ia tak dapat melayani suaminya bila menopause tiba dan kuatir suaminya berpaling mencari perempuan lain.

Bila laki-laki/suami mengerti kondisi ini, tentu persoalan akan lebih mudah dihadapi. Sementara apabila kondisi tersebut tidak dipahami dengan baik maka dapat berdampak ganda, baik kepada perempuan itu dan perempuan lain. Perempuan yang menganggap dirinya tak mampu memenuhi tuntutan keluarga, budaya dan masyarakat akan tiba pada tingkat stress yang tinggi dan menyalahkan diri (serta rahimnya). Pada akhirnya, ia akan memandang perempuan lain sebagai ancaman bagi eksistensinya. Akibatnya, dalam heterophobia yang berlebihan, ada kemungkinan ia menemukan sasaran agresinya pada perempuan lain itu.

Kondisi tersebut diperkuat dengan arus budaya pop yang muncul melalui media televisi maupun media sosial. Lihatlah bagaimana sinetron TV atau meme media 
sosial memberi informasi untuk mewaspadai pelakor (singkatan dari "perebut laki orang") yang membuat perempuan dengan perempuan (termasuk sahabat atau saudara) untuk hidup dengan saling curiga. Dalam keadaan demikian, yang paling diuntungkan adalah laki-laki yang memang sedang ingin "direbut" untuk menjadi "milik" perempuan lain.

\section{PEMBAHASAN}

- Menyimak Sejarah: Pengalaman Rahim (Perempuan) di Poso dalam Perspektif Misi

Orang Poso patut bersyukur, sebab konstruksi masyarakatnya dapat disebut egaliter. Perempuan (dengan karunia khusus) ditempatkan dalam kedudukan tinggi sebagai Tadumburake (pemimpin upacara mowurake) ${ }^{5}$ atau Tadu Pojamaa, ${ }^{6}$ pemimpin dalam upacara (siklus) pertanian. Namun demikian, bahasa Poso yang diberikan untuk seorang perempuan yang menstruasi adalah tobela atau keangga. Sebagaimana Kamus Bahasa Poso Dj. Tiladuru, bela atau angga adalah sejenis jin yang ditakuti. Dapatlah dikatakan pula bahwa pandangan orang Poso tentang menstruasi sebagai pengalaman ketubuhan perempuan, meminjam pendapat Freud tentang ambivalensi tabu menstruasi, ${ }^{7}$ adalah kotor dan terkena kekuatan jahat sehingga perlu dijauhi.

Pandangan demikian hidup dalam banyak budaya. Orang Bali, misalnya, tidak memperbolehkan perempuan haid pergi ke hutan, sebab hutan dipandang suci. Contoh lain misalnya di Papua, masyarakat menempatkan perempuan haid di pondok-pondok yang dibuat jauh dari pemukiman penduduk. Sementara dalam masyarakat Poso, perempuan haid dilarang memetik tangkai seledri, sebab dianggap menyebabkan layu dan mati. Di Panjoka, dimana penulis pernah menjadi pendeta jemaat, terdapat Legenda Ue Moleke, ${ }^{8}$ yang mengaitkan kisah terjadinya Ue Moleke dengan perempuan yang sedang menstruasi.

Penelitian tentang konteks masyarakat terkait dengan rahim perempuan, terutama beruhubungan dengan kelahiran dan ketahanan bayi, telah dilakukan oleh Tillema, Kruyt dan Adriani. Informasi menarik tentang rahim (perempuan) di Poso berdasarkan survey yang dilakukan pada sekitar tahun 1902-1924 tersebut, dapat dilihat pada tabel di bawah ini. 
Tabel 1:

Fertilitas Ibu dan Survivalitas Anak Pada Kelompok Suku di Poso (1924)

\begin{tabular}{|l|l|l|l|l|l|}
\hline \multicolumn{2}{|c|}{ Indikator Dan Kelompok Sub Suku } & \multicolumn{3}{|l|}{$\begin{array}{l}\text { Sub Suku Yang } \\
\text { Memiliki Watua }\end{array}$} & $\begin{array}{l}\text { Sub Suku Yang } \\
\text { Tidak } \\
\text { Watua }\end{array}$ \\
\cline { 2 - 6 } & To Lage & $\begin{array}{l}\text { To } \\
\text { Onda'e }\end{array}$ & $\begin{array}{l}\text { To } \\
\text { Pebato }\end{array}$ & $\begin{array}{l}\text { To } \\
\text { Wingke } \\
\text { mPoso }\end{array}$ \\
\hline 1. & $\begin{array}{l}\text { Rerata Angka Kelahiran Total } \\
\text { (AKT) per ibu } \\
\text { (fertility rate) }\end{array}$ & 2.75 & 2.53 & 3.22 & 3.83 \\
\hline $\begin{array}{l}\text { 2. } \\
\text { Rerata Angka Harapan Hidup pada } \\
\text { Waktu Lahir (survivality rate) }\end{array}$ & 1.31 & 1.30 & 1.57 & 2.03 \\
\hline Margin = Angka Kematian Bayi & $\mathbf{1 . 4 4}$ & $\mathbf{1 . 2 3}$ & $\mathbf{1 . 6 5}$ & $\mathbf{1 . 8 0}$ \\
\hline
\end{tabular}

Sumber: Henley (2005: 371)

Informasi pada Tabel 1 menunjukkan bahwa baik kelompok suku yang memiliki watua (budak) maupun kelompok suku yang tidak memiliki watua tidak terlalu berpengaruh kepada margin angka kelahiran total dan angka harapan hidup pada waktu lahir. Selisih angka dari kedua kelompok sub-suku dalam penelitian tersebut tidak terlalu signifikan, artinya, stratifikasi sosial tidak banyak berperan dalam fertilitas rahim dan survivalitas bayi. Henley menduga bahwa kondisi ini terjadi karena kultur orang Poso yang pada dasarnya bersifat matrilineal. ${ }^{9}$ Dengan kata lain, walaupun seorang perempuan memiliki status sosial sebagai watua, tetapi tampaknya ia diperlakukan cukup baik oleh kabose (tuan)-nya.

Selanjutnya, Kruyt juga membandingkan data fertilitas ibu dan survivalitas anak diantara kelompok masyarakat yang masih menganut agama suku (agama suku molamoa) dengan kelompok masyarakat Muslim di Poso. Hasil perbandingan tersebut dapat dilihat pada tabel di bawah ini. 
Tabel 2:

Fertilitas Ibu dan Survivalitas Anak Pada Kelompok Agama Suku dan Kelompok Muslim di Poso (1902)

\begin{tabular}{|c|c|c|c|c|c|}
\hline \multirow{2}{*}{\multicolumn{2}{|c|}{ Indikator Dan Kelompok Agama }} & \multicolumn{2}{|c|}{ Agama Suku } & \multicolumn{2}{|l|}{ Muslim } \\
\hline & & To Lage & To Pebato & Mapane & Tojo \\
\hline \multicolumn{6}{|c|}{ Semua Perempuan } \\
\hline 1. & $\begin{array}{lll}\text { Rerata Angka } & \text { Kelahiran } & \text { Total } \\
(\mathrm{AKT}) \text { per ibu } & & \\
(\text { fertility rate }) & & \end{array}$ & 2.85 & 4.03 & 3.82 & 2.50 \\
\hline 2. & $\begin{array}{l}\text { Rerata Angka Harapan Hidup pada } \\
\text { Waktu Lahir (survivality rate) }\end{array}$ & 1.24 & 3.12 & 3.13 & 1.88 \\
\hline \multicolumn{2}{|r|}{ Margin = Angka Kematian Bayi } & 1.61 & 0.91 & 0,69 & 0.62 \\
\hline
\end{tabular}

Sumber: Henley (2005: 374)

Tabel tersebut menunjukkan jumlah margin yang cukup signifikan, terutama bila membandingkan kelompok agama suku To Lage dengan kelompok Muslim. Dari 285 angka kelahiran dari perempuan To Lage, 161 di antaranya meninggal. Perbedaan yang cukup signifikan jika dibandingkan dengan kelompok Muslim Mapane, dari 382 kelahiran, "hanya" 69 anak yang meningggal. Sementara itu, diketahui bahwa perempuan dari kelompok suku To Pebato memiliki tingkat fertilitas yang paling tinggi, dimana dari 100 perempuan, terdapat 403 anak yang dilakhirkan dan 312 diantaranya bertahan hidup sampai dewasa. Bila membandingkan Tabel 1 dan Tabel 2, tampak bahwa tingkat kesuburan (fertility) perempuan Poso tergolong tinggi, tetapi tidak diikuti dengan kemampuan untuk mempertahankan hidup bayi. Terdapat beberapa faktor yang menjadi penyebab terjadinya hal tersebut. Pertama, sebagaimana informasi yang didapat dari Schrauwers, ${ }^{10}$ bahwa kurangnya asupan kalsium-laktat bagi ibu hamil, mengingat model rumah tangga orang Poso adalah extended family (keluarga besar) dengan prinsip shared poverty (berbagi kemiskinan; istilah yang dicetuskan oleh Antropolog Clifford Geertz). Dalam prinsip shared poverty, sesedikit apapun makanan yang didapat, semua mesti mendapatkan secukupnya. Kedua, usia pernikahan perempuan yang terlalu dini. Kruyt menyebutkan, sebagaimana dicatat Henley, ${ }^{11}$ rata-rata perempuan Poso menikah pada usia 15 tahun (bandingkan Undang-Undang 
Perkawinan No. 1 Tahun 1974 Pasal 7 yang menyebut usia minimal perempuan menikah adalah 16 tahun). Pernikahan pada usia tersebut dapat digolongkan dini, dan hal tersebut berpengaruh pada kesehatan janin dalam rahim. Dilansir dari kompas.com diketahui bahwa pengaruh pernikahan usia dini pada janin/bayi adalah resiko kematian yang lebih besar, kelahiran bayi prematur, anak kurang gizi, dan beresiko mengalami hambatan pertumbuhan (stunting).

Tentang hal yang terakhir, selain faktor resiko pernikahan dini yang berakibat pada kesehatan janin dan bayi, Kruyt dan Adriani juga mengatakan bahwa anak-anak di Poso berada pada "situasi pola makan yang buruk" sebab anak-anak itu "tidak tumbuh cepat". ${ }^{12}$ Untuk menghadapi kondisi ini, Kruyt meminta bantuan seorang dokter militer, De Wijn. Penelitiannya kepada 2.517 anak usia enam sampai 18 tahun di Poso dan Mori, menunjukkan bahwa pada usia 15 tahun, anak laki-laki Poso 10 sentimeter lebih pendek dan lima kilogram lebih ringan dibanding anak-anak sebayanya di tempat lain di Hindia Belanda, khususnya di Jawa dan Bali. Masalah pola makan buruk tersebut juga menjadi penyebab tingginya angka kematian pada bayi dan anak. Selain itu, dicatat juga bahwa orang dewasa di Poso - yang lebih banyak berperang, mengumpulkan hasil hutan, dan membuat garam dengan meninggalkan kampung berhari-hari - hanya makan dua kali sehari dengan "sedikit sayuran dan ikan", sedangkan anak-anak lebih sering hanya makan nasi, yang menyebabkan kurangnya protein dan nutrisi lain.

Menghadapi situasi yang bermula dari persoalan di sekitar rahim ini, Kruyt menempuh berbagai macam cara. Pertama, Kruyt mengupayakan agar sesegera mungkin sekolah-sekolah didirikan dengan mendatangkan guru-guru Injil dari Minahasa. Menurut hemat penulis, hal ini dilakukan agar semakin banyak orang Poso, khususnya anak-anak, selain dapat belajar mengenal huruf dan memahami Injil, tetapi juga mencegah terjadinya pernikahan dini. Oleh karena itu, tidak mengherankan apabila dalam waktu yang relatif singkat Kruyt, dengan bantuan penginjil lain dan guru-guru Injil, dapat mendirikan 300 sekolah di berbagai tempat di Poso. ${ }^{13}$

Kedua, untuk kecukupan makan dan gizi, pada 1906 dan 1908, Kruyt (memaksa) melakukan pemindahan (resettlement) orang Poso dari pegunungan ke dataran rendah untuk mengubah cara bertani dari pertanian berbasis ladang yang menghasilkan padi sedikit menjadi pertanian berbasis padi sawah yang dipandang 
lebih menghasilkan banyak. ${ }^{14}$ Penelitian Davis, sebagaimana dikutip Sangadji, ${ }^{15}$ menemukan bahwa pada tahun 1920-an Kruyt menyuruh orang Poso (Buyu mPondoli) belajar bersawah kepada orang Bali (buangan politik) di Parigi-Moutong (Desa Mertasari kini).

Ketiga, untuk menekan angka kematian bayi, termasuk juga penyakitpenyakit lainnya, diperlukan pusat kesehatan sebagai upaya membantu tugas pekabaran Injil, dan karena itu Kruyt meminta Lembaga Misi Belanda (NZG) untuk mendatangkan suami-istri Schuyt untuk bekerja di Kuku lalu ke Tentena, yang kemudian diikuti oleh De Wijn, Arie Kruyt (anak A.C. Kruyt), dan lain-lain untuk menjadi tenaga kesehatan di Poso. Dibukanya pelayanan Rumah Orang Bersalin (ROB), yang turut didukung oleh Perempuan Gereja Kristen Sulawesi Tengah GKST menjadi cikal bakal Rumah Sakit Sinar Kasih GKST.

Keempat, menghapus perbudakan dan pengayauan (potong kepala). Meskipun data survey pada Tabel menunjukkan bahwa tidak ada korelasi langsung antara kehamilan dengan perbudakan, tampaknya Kruyt telah dengan sangat hati-hati melakukan rekayasa sosial terhadap stratifikasi masyarakat Poso. Keberhasilan ini menjadi peletak dasar dari perjumpaan semangat egalitarianisme Kristen dengan sistem matrilineal orang Poso. Masyarakat mesti dibebaskan dari sistem perbudakan, sehingga kebebasan perempuan dan laki-laki berguna bagi perhatian kepada rahim dan janin/bayinya. Demikian pula dengan pengayauan, dimana penghapusan pengayauan yang seringkali menjadi alasan terjadinya perang antar suku membuat masyarakat Poso hidup dalam damai sebagaimana iman Kristen. Tampaknya Kruyt menyadari bahwa dalam perang dan kekerasan, perempuan dan anak selalu menjadi korban. Penghapusan praktik mengayau membuat masyarakat (orang dewasa) fokus kepada pekerjaan dan perhatiannya kepada keluarganya.

\section{- Tugas Gereja: Kini dan Nanti}

Alur pembahasan materi ini menyisakan pertanyaan: jika Kruyt bersama penginjil yang lain telah meletakkan dasar bagi pelayanan gereja di masa lampau dengan berangkat dari pengalaman rahim perempuan, bagaimana gereja di masa kini memahami panggilannya? Meskipun upaya untuk memahami panggilan gereja masih terlihat, akan tetapi hal itu tampaknya tenggelam oleh seremonia simbolis kekristenan yang ditopang oleh histeria pembangunan gedung gereja. Simbol-simbol 
dan penghayatan terhadapnya tentu penting, tetapi gereja mesti bergerak melampaui simbol-simbol tersebut. Sama seperti pelampauan penghayatan terhadap roti dan anggur perjamuan kudus, bahwa yang kelihatan itu hanyalah sarana untuk memahami kasih karunia keselamatan Allah yang rahimi dan rahmani itu.

GKST, sebagai gereja yang tumbuh di Sulawesi Tengah dan sebagian Sulawesi Selatan, yang dipengaruhi oleh semangat Calvinis tampaknya mesti melihat Calvin yang memandang gereja sebagai ibu. Sebagaimana Boehlke ${ }^{16}$ mengutip Institutio Calvin,

“... Bagi kita, tidak ada jalan masuk ke dalam kehidupan kalau kita tidak dikandung di dalam rahimnya, dilahirkan olehnya, disusuinya, dan akhirnya dilindungi dan dibimbingnya, sampai kita menanggalkan daging yang mesti mati ini dan menjadi sama dengan malaikat."

Gereja mesti menjadi ibu, sebagai alat kasih Allah laksana Rahim. Selain itu, gereja juga dipanggil untuk merahimi dan merahmati. Gereja adalah semua orang percaya yang dipanggil untuk berempati dengan pengalaman kerahiman. Beberapa isu penting terkait rahim dan perempuan dan sikap gereja dalam merespon persoalan tersebut ialah sebagai berikut. Pertama, bagaimana gereja bersikap terhadap Kehamilan yang Tak Diinginkan? Pada kasus anak gadis hamil di luar nikah, gereja seringkali memulai dengan penetapan waktu penggembalaan terhadapnya. Yang terjadi bukanlah fungsi penggembalaan yang menyembuhkan, mendukung, membimbing, memulihkan, dan memelihara, ${ }^{17}$ melainkan tindakan disiplin/siasat: bahwa dia berdosa dan harus bertobat. Institusi gereja memandangnya sebagai pendosa, sehingga ia tidak layak bagi perjamuan Tuhan dan anak yang dilahirkan juga dianggap tidak suci bagi baptisan kudus. Pertobatan dan babtisan adalah tanda dimana janji keselamatan Allah yang menebus manusia yang berdosa dinyatakan.

Rahimi dan rahmatkah, saat semua orang percaya dipanggil untuk menerima roti dan anggur atau menjadi saksi bagi peristiwa terhisabnya seseorang dalam persekutuan orang percaya bahwa ia telah diselamatkan Kristus dari dosa-dosanya, ada orang yang dipandang oleh gereja berdosa dan tak layak? Tidak hanya itu, orangorang lain (warga jemaat yang mendengar namanya dibacakan atau didoakan) juga memandangnya sebagai yang paling berdosa dan menganggap diri sebagai yang paling benar, seperti para ahli Taurat yang membawa seorang perempuan yang kedapatan berbuat zinah kepada Yesus (Yoh. 7:53-8:11). Padahal, orang-orang lain 
juga memiliki potensi untuk melakukan dosa dalam kesempatan dan bentuk yang lain. Gereja sering lupa bahwa orang percaya adalah orang berdosa yang menuntun orang berdosa lain untuk mengharapkan kasih karunia Allah semata (sola gratia), dan oleh imannya (sola fide) kepada Kristus yang mati dan bangkit ia dibenarkan dari dosa-dosanya (simul iustus et peccator).

Seorang perempuan yang mengalami "kehamilan yang tidak diinginkan" seringkali hanya diperhadapkan pada satu pilihan: menikah. Jalan keluar ini seringkali mengabaikan kesiapan mental dan kematangan usia untuk menikah. Dampaknya, ia meninggalkan sekolah dan masa depannya. Selain itu, ia sering tidak didampingi secara psikologis, sosial, dan kesehatan untuk menghadapi situasi yang tak diduganya sehingga dapat membuatnya depresi yang juga berdampak terhadap janinnya. Karena itu, patutlah didukung perjuangan beberapa kelompok orang untuk mendesak DPR-RI merevisi UU Perkawinan No. 1/1974 dengan tujuan mengubah batas usia pernikahan perempuan dari 16 tahun menjadi 18 tahun sebagaimana keputusan Mahkamah Konstitusi Republik Indonesia.

Kedua, bagaimana gereja bersikap terhadap Angka Kematian Ibu dan Anak? Patut disyukuri bahwa kemajuan ilmu kedokteran dan kebijakan kesehatan masyarakat mendukung bagi peningkatan kualitas hidup Ibu dan Anak. Berdasarkan survey kesehatan Kabupaten Poso tahun 2011-2015, terjadi fluktuasi jumlah kematian Ibu dan Anak, termasuk Angka Kematian Balita. Rata-rata Angka Kematian Ibu (Maternal Mortality Rate) pada rentang waktu tersebut adalah 6.8 per tahun, dengan penyebab terbesarnya adalah eklampsia. Sementara rata-rata Angka Kematian Bayi pada rentang waktu itu adalah 43.6 per tahun, dengan penyebab terbesarnya adalah asfiksia. Sedangkan rata-rata Angka Kematian Balita adalah 2.2 per tahun, dengan penyebab utama adalah infeksi akut paru yang disebabkan oleh bakteri. $^{18}$

Tentang sikap gereja terhadap hal ini, tampaknya gereja (khususnya jemaat lokal) menyerahkan sepenuhnya kepada pemerintah. Padahal, telah dilihat bahwa dalam sejarahnya gereja juga turut peduli terhadap kondisi kesehatan ibu dan anak. Ini berarti bahwa dewasa ini gereja perlu bersinergi untuk meningkatkan kualitas hidup perempuan dan anak yang adalah warga gereja di seputar kerahimannya. Ini bukan hanya tugas persekutuan perempuan, tetapi juga tugas kategorial yang lain, seperti remaja, pemuda, dan bapak; masing-masing dengan kapasitas dan tujuan 
perannya. Karena itu, perlu dilacak isi pertemuan-pertemuan kategorial di jemaatjemaat. Jangan-jangan pengaruh pietisme ${ }^{19}$ penginjil Barat masih memengaruhi teologi gereja-gereja di Indonesia yang memahami teologi keselamatan yang bersifat rohani atau futuristik dan sangat individualistik, sehingga menjadi sangat acuh tak acuh dengan situasi di masa kini. ${ }^{20}$ Khotbah yang melulu membicarakan keselamatan "di seberang sana" pasti mengabaikan "kenyataan masa kini". Menurut penulis, karya hari ini dengan membincangkan rahim dari berbagai perspektif, adalah upaya untuk mengarahkan perhatian kepada kemanusiaan masa kini, kepada kegelisahan terhadap derita rahim. Persoalannya, berapa banyak pendeta dan jemaat yang melihat hal ini sebagai persoalan teologis, dan sejauh mana sinergi kelompok dan kategorial dalam jemaat memikirkan dalam diskusi-diskusi Alkitab (PA)?

Ketiga, bagaimana gereja bersikap terhadap kekerasan seksual, baik dalam keluarga maupun dalam pacaran? Menurut Komnas Perempuan, terdapat 15 bentuk kekerasan seksual, yakni perkosaan, intimidasi seksual termasuk ancaman atau percobaan seksual, pelecehan seksual, eksploitasi seksual, perdagangan perempuan untuk tujuan seksual, prostitusi paksa, perbudakan seksual, pemaksaan perkawinan termasuk cerai gantung, pemaksaan kehamilan, pemaksaan aborsi, pemaksaan kontrasepsi dan sterilisasi, penyiksaan seksual, penghukuman tidak manusiawi dan bernuansa seksual, praktik tradisi bernuansa seksual yang membahayakan atau mendiskriminasi perempuan, kontrol seksual termasuk aturan diskriminatif beralasan moralitas dan agama. Sembilan di antara berbagai bentuk kekerasan tersebut sedang diupayakan masuk dalam RUU Penghapusan Kekerasan Seksual, yang sampai hari ini belum disahkan oleh DPR RI.

Persoalan kekerasan seksual sering luput dari perhatian gereja, atau gereja seolah-olah menganggap hal ini sebagai sesuatu yang bukan urusannya. Bahkan apabila gereja menjumpai kasus kekerasan seksual, gereja tampaknya mencari jalan nyaman melalui tindakan pastoral yang lebih sering menyalahkan korban. Namun, gereja juga seringkali berada pada posisi yang tidak mudah sebab penanganan persoalan diharapkan berimbang, tetapi persoalan kekerasan seksual menuntut keberpihakan terhadap korban.

Dalam masyarakat patriarki, alih-alih memihak korban (privilege for the victim), yang terjadi justru masyarakat lebih banyak menyalahkan korban (blaming the victim). Akibatnya, korban cenderung memilih diam dan menerima begitu saja 
(taken for granted) perlakukan kekerasan seksual yang dialaminya. Dilansir dari Tirto.id, berdasarkan survey pada tahun 2016 yang dilakukan oleh Lentera Sintas Indonesia dan Magdalene.co serta difasilitasi oleh Change.org, ditemukan bahwa di Indonesia 93\% mereka yang mengalami kekerasan seksual tidak pernah melaporkan kasusnya ke penegak hukum. Hasil survey BPS juga menunjukkan bahwa satu dari tiga perempuan pernah mengalami kekerasan fisik atau seksual selama hidupnya. Selain itu, berdasarkan data yang dimuat pada laman Tirto.id, berdasarkan informasi yang dirangkum dari berbagai sumber, kekerasan dominan dialami oleh perempuan dan anak, dan yang paling tinggi terjadi di ranah personal. Artinya, pelaku adalah orang yang memiliki hubungan darah (ayah, kakak, adik, paman, kakek), kekerabatan, perkawinan (suami) maupun relasi intim (pacaran dengan korban).

Faktor yang disebut terakhir di atas adalah isu yang menghangat belakangan ini. Dilansir dari Magdalene.co, Komnas Perempuan menyebutkan bahwa pada tahun 2017 terdapat $21 \%$ kasus kekerasan dalam pacaran yang dilaporkan. Kekerasan dalam pacaran, khususnya terhadap perempuan, terjadi karena adanya ketimpangan kuasa sehingga ada keinginan untuk mengontrol pasangannya. Budaya patriarki menganggap bahwa cinta adalah kepemilikan (property). Dalam banyak kasus, korban tidak menyadari kondisi tersebut. Ia memandang hal itu sebagai "tanda cinta" yang "rela berkorban" apapun demi pacarnya. Celakanya, seks seringkali dipakai sebagai senjata untuk mengontrol. Jika ia sudah berhubungan seks dengan pacarnya, maka ia berhak memiliki hidup pasangannya. Dalam masyarakat patriarki, dimana konsep keperawanan dan seksualitas dianggap sebagai tabu, perempuan tetap bertahan dalam jebakan "pacaran beracun" (toxic relationship) karena takut dihakimi.

\section{PENUTUP: Rahim yang Memiliki Spektrum Luas}

Diskursus tentang Rahim, sebagaimana telah dipaparkan, dengan jelas memiliki spektrum yang luas. Rahim (perempuan) menjadi pusat untuk menjelaskan berbagai hal dalam seluruh dimensi kehidupan masyarakat. Dari padanya berbagai hal dapat dipahami. Rahim, yang menjadi simbolisasi kasih dan rahmat Allah bagi manusia berdosa, diberi kepada perempuan untuk menunjukkan kepada semua manusia (laki-laki dan perempuan) bahwa ia mesti dihargai dan dihormati. Dalam teologi Kristen, pemberian selalu bermakna penugasan. Karunia rahim berarti 
tanggung jawab terhadapnya, yang berlaku baik bagi perempuan pemilik Rahim dan juga bagi laki-laki yang berasal dari rahim. Penghargaan dan penghormatan kepada rahim adalah simbolisasi perwujudan ketaatan kepada Allah Yang Maha Pengasih lagi Maha Penyayang.

\section{Endotes :}

\footnotetext{
${ }^{1}$ Tampaknya konsep rahim juga dapat menjadi titik temu bagi hidup beragama di Tana Poso. Penulis tidak akan membahas hal ini lebih jauh dalam paper ini, mengingat ruang yang sangat terbatas.

${ }^{2}$ Irwan Abdullah, "Mitos Menstruasi: Konstruksi Budaya Atas Realitas Gender," Humaniora 14 (2002): 34.

${ }^{3}$ Ratna Noviani, "Multiplisitas Wajah Rahim: Karya Seni Sebagai Narasi Feminis," Jurnal Kajian Seni 01, no. 2 (2015): 102.

${ }^{4}$ Jeannete E. South-Paul, Samuel C. Matheny, and Evelyn L. Lewis, Diagnosis \& Terapi Terkini: Kedokteran Keluarga (Jakarta: EGC, 2014), 594

${ }^{5}$ Mowurake adalah upacara untuk dua peristiwa: 1) dilakukan untuk mengupayakan tanoana (roh) orang sakit yang pergi agar kembali ke tubuhnya. Orang Poso percaya bahwa orang menjadi sakit karena tanoana-nya pergi meninggalkannya; 2) dilakukan dalam upacara mompemate (ritus kematian) untuk membuat roh orang mati (angga) menjadi tanoana/lamoa (roh lelulur) yang dihormati.

${ }^{6}$ Siklus pertanian orang Poso, yang berbasiskan padi ladang, meliputi tahapan 1) mampeoleka Betu'e Tamangkapa [melihat Bintang Orion], 2) madika patira [menentukan batas ladang], 3) mombaakati [membersihkan ladang], 4) тотиуа [menanam], 5) mampapotanoana pae [memberi roh pada padi], 6) momota [memanen], 7) mangore [makan padi baru], 8) mopadungku (syukur panen bersama).

${ }^{7}$ Abdullah, "Mitos Menstruasi: Konstruksi Budaya Atas Realitas Gender," 35.

8 Alkisah, seorang perempuan haid sedang menjahit pakaian yang robek. Ia ditemani oleh seekor kucing. Tak sengaja, jarumnya jatuh. Ia terpaksa menyuruh si kucing untuk mengambil jarum tersebut, sebab ia tak mungkin turun karena sedang haid. Adalah hal yang tidak diperkenankan untuk menyuruh kucing, yang disebut pue mbalesu (tuannya tikus), untuk mengambil sesuatu yang bukan tugasnya. Akibatnya, dari seluruh tiang-tiang rumah panggung muncul mata air sampai menenggelamkan rumah dan perempuan tersebut. Kini, apabila ada orang yang mendekati area itu sambil bersuara, maka genangan air di situ akan berbual/mendidih.

${ }^{9}$ David Henley, Fertility, Food and Fever: Population, Economy and Environment in North and Central Sulawesi (Leiden: KITLV Press, 2005), 374.

${ }^{10}$ Arianto Sangadji and Albert Schrauwers, Colonial 'Reformation' in the Highlands of Central Sulawesi, Indonesia. (Toronto: University of Toronto Press, 2000), 100.

${ }^{11}$ Henley, Fertility, Food and Fever: Population, Economy and Environment in North and Central Sulawesi, 374.

${ }^{12}$ Henley, 344-45

${ }^{13}$ Sangadji and Schrauwers, Colonial 'Reformation' in the Highlands of Central Sulawesi, Indonesia., 221.

${ }^{14}$ Sangadji and Schrauwers, 71.

${ }^{15}$ Sangadji and Schrauwers, 1.

${ }^{16}$ Robert Boehlke, Sejarah Perkembangan Pemikiran Dan Praktek Pendidikan Agama Kristen: Dari Plato Sampai Ignatius Loyola (Jakarta: BPK Gunung Mulia, 2006), 402.

${ }^{17}$ Howard Clinebell, Tipe-Tipe Dasar Pendampingan Dan Konseling Pastoral (Jakarta - Yogyakarta: BPK Gunung Mulia - Kanisius, 2002), 55.

${ }^{18}$ Tim Penyusun, Profil Kesehatan Kabupaten Poso Tahun 2015 (Poso: Dinas Kesehatan Kab. Poso, 2016), 9-11.
} 
${ }^{19}$ Dari kata pietas, yang berarti "saleh"; pietisme awalnya adalah gerakan yang berupaya agar orang Kristen hidup saleh di tengah situasi bergereja yang terlalu melembaga. Keselamatan yang dipahami bersifat futuristik dan individualistik. Akan tetapi, demi masa depan itu, diperlukan sikap di masa kini untuk menyongsongnya. Pekerjaan Allah di masa yang akan datang mesti juga direalisir oleh gereja di masa kini. Gerakan ini juga yang memengaruhi lembaga zending NZG yang menugaskan Kruyt ke Poso. Belakangan, gerakan ini acuh tak acuh dengan kehidupan masa kini, sebab melulu melihat keselamatan sebagai sesuatu yang ada di masa depan (Hale, 1996).

${ }^{20}$ Emanuel G. Singgih, Mengantisipasi Masa Depan (Jakarta: BPK Gunung Mulia, 2003), 352.

\section{DAFTAR PUSTAKA}

Abdullah, Irwan. "Mitos Menstruasi: Konstruksi Budaya Atas Realitas Gender." Humaniora 14 (2002).

Boehlke, Robert. Sejarah Perkembangan Pemikiran Dan Praktek Pendidikan Agama Kristen: Dari Plato Sampai Ignatius Loyola. Jakarta: BPK Gunung Mulia, 2006.

Clinebell, Howard. Tipe-Tipe Dasar Pendampingan Dan Konseling Pastoral. Jakarta

- Yogyakarta: BPK Gunung Mulia - Kanisius, 2002.

Henley, David. Fertility, Food and Fever: Population, Economy and Environment in North and Central Sulawesi. Leiden: KITLV Press, 2005.

Noviani, Ratna. "Multiplisitas Wajah Rahim: Karya Seni Sebagai Narasi Feminis." Jurnal Kajian Seni 01, no. 2 (2015).

Penyusun, Tim. Profil Kesehatan Kabupaten Poso Tahun 2015. Poso: Dinas Kesehatan Kab. Poso, 2016.

Sangadji, Arianto, and Albert Schrauwers. Colonial 'Reformation' in the Highlands of Central Sulawesi, Indonesia. Toronto: University of Toronto Press, 2000.

Singgih, Emanuel G. Mengantisipasi Masa Depan. Jakarta: BPK Gunung Mulia, 2003.

South-Paul, Jeannete E., Samuel C. Matheny, and Evelyn L. Lewis. Diagnosis \& Terapi Terkini: Kedokteran Keluarga. Jakarta: EGC, 2014. 